\begin{tabular}{c|c|c|} 
CRITICAL & $\begin{array}{l}\text { WCOSYSTEM } \\
\text { PARTERSHIP FUND }\end{array}$ & $\begin{array}{l}\text { Western Ghats } \\
\text { Special Series }\end{array}$ \\
\cline { 2 - 3 } & Meghamalai special section \\
\cline { 3 - 3 } &
\end{tabular}

\title{
ANURANS OF the MeghamalaI LANDSCAPE, WeStern GHATS, INDIA
}

\section{G. Srinivas ${ }^{1} \&$ Subramanian Bhupathy ${ }^{2}$}

${ }^{1}$ Wildlife Information Liaison Development Society, 96 Kumudham Nagar, Vilankurichi Road, Coimbatore, Tamil Nadu 641035, India

1,2 Sálim Ali Centre for Ornithology and Natural History, Anaikatti (PO), Coimbatore, Tamil Nadu 641108, India

${ }^{1}$ sriniherp@gmail.com (corresponding author), ${ }^{2}$ bhupathy.s@gmail.com

Abstract: Meghamalai landscape, southern Western Ghats was surveyed for anurans from March 2006 to January 2009. Including published data, a total of 35 species of anurans belonging to 19 genera and eight families have been reported from the area. This includes 23 (65.7\%) species endemic to the Western Ghats. New locality records for four species namely, Fejervarya mudduraja, Raorchestes griet, $R$. ponmudi and Rhacophorus pseudomalabaricus were obtained. Several species recorded from the area are listed under various threat categories of IUCN Red List. Further studies are required to understand the ecological requirements of the anurans of the landscape.

Keywords: Anuran diversity, conservation status, endemic species, High Wavy Mountains.
Globally 7,044 species of amphibians have been reported (Frost 2013), and 342 species are known from India (Dinesh et al. 2012). Of the 157 species reported from the Western Ghats, 135 (85.99\%) are endemic to the hill range (Dinesh \& Radhakrishnan 2011). Though there are few studies that have looked at the ecological aspects of the amphibians in the Western Ghats, inventories of amphibians are available for many parts of the Ghats; 33 species from the Kerala part of the Nilgiri Biosphere Reserve (Easa 1998), 35 from Kalakad Wildlife Sanctuary (Cherian et al. 2000), 32 from KalakadMundanthurai Tiger Reserve (Vasudevan et al. 2001), and 40 from Anamalai Hills (Kumar et al. 2001) which are adjacent or in close vicinity to the Meghamalai area.

Meghamalai landscape is situated in the southern

DOI: http://dx.doi.org/10.11609/JoTT.03593.4973-8 | ZooBank: urn:Isid:zoobank.org:pub:5A2884C3-B85B-414A-958F-1233FB0253A2

Manuscript details: Ms \# 03593 | Received 26 April 2013 | Final received 03 August 2013 | Finally accepted 10 October 2013

Citation: Srinivas, G. \& S. Bhupathy (2013). Anurans of the Meghamalai landscape, Western Ghats, India. Journal of Threatened Taxa 5(15): 4973-4978; http:// dx.doi.org/10.11609/JoTT.03593.4973-8

Copyright: @ Srinivas \& Bhupathy 2013. Creative Commons Attribution 3.0 Unported License. JoTT allows unrestricted use of this article in any medium, reproduction and distribution by providing adequate credit to the authors and the source of publication.

Funding: Ministry of Environment and Forests (MoEF), Government of India.

Competing Interest: Authors declare no competing interests.

Acknowledgements: This paper is an offshoot of a research project funded by the Ministry of Environment and Forests (MoEF), Government of India. We are thankful to G.V. Subramanian and Naseem Ahmad (MoEF) for financial support; R. Sundararaju (PCCF \& Chief Wildlife Warden) and Srinivas R. Reddy (District Forest Officer) for permission to work in the forest area and logistic support, and P.A. Azeez and N. Sathish Kumar and other colleagues at the Sálim Ali Centre for Ornithology and Natural History, Coimbatore, for encouragement and support at various levels. We thank K.V. Gururaja for helping us in species identification; and Yesudoss, Kumar and Munusamy for helping us in the fieldwork.

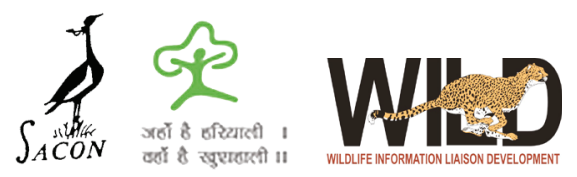

The publication of this article is supported by the Critical Ecosystem Partnership Fund (CEPF), a joint initiative of I'Agence Française de Développement, Conservation International, the European Commission, the Global Environment Facility, the Government of Japan, the MacArthur Foundation and the World Bank. 
Western Ghats, which is also known as High Wavy mountains. An understanding of its biodiversity is very crucial, this has been highlighted by Bhupathy et al. (2012). However, no such exploration was carried out in the Meghamalai landscape especially on amphibians. A study on the herpetofaunal mortality due to vehicular traffic along the interstate National Highway CumbumKumuly (NH 220), that cuts across the landscape is available (Bhupathy et al. 2011). In the present paper, we provide data on the amphibian fauna of Meghamalai landscape based on a study from March 2006 to January 2009 and published literature.

\section{Materials and Methods}

Time-constrained visual encounter surveys (TCVES) and quadrat search (size: 10×10 m) as described in Heyer et al. (1994) were used for data collection in three belt transects for a period of two years between December 2006 and November 2008 on a seasonal basis; dry (December-May) and wet (June-November) seasons (also see Bhupathy et al. 2009; Bhupathy \& Sathishkumar 2013). These transects (fixed width of $1000 \mathrm{~m}$ ) were located in Mavadi, Suruli and Vellimalai areas of Meghamalai (Fig. 1), and they measured $8.00 \mathrm{~km}, 6.86 \mathrm{~km}$ and $6.31 \mathrm{~km}$ in length respectively. On each belt transect, 100 hours (x 3 men), i.e., 300 man- hours of visual encounter survey and 100 quadrats of 1ha were sampled during each dry and wet season. In all, 3600 man-hours of TCVES and 1200 auadrats (12ha) were examined. In addition, opportunistic observations of anurans in the area during March 2006 to January 2009 and data on anuran mortality in a $6 \mathrm{~km}$ length of the Cumbum-Kumuly National Highway 220 that cut across Meghamalai landscape (see Bhupathy et al. 2011) were considered for analysis.

The anurans observed were identified based on keys and other publications (e.g., Vasudevan \& Dutta 2000; Bossuyt 2002; Biju \& Bossuyt 2005; Daniels 2005; Kuramoto et al. 2007), further the species identity was confirmed by K.V. Gururaja (Centre for infrastructure, Sustainable Transport and Urban planning CISTURB). Nomenclature followed herein is of Frost (2013), and the assessment of threat status of anuran species observed in the area was based on IUCN Red List (2013).

\section{Results and Discussion}

A total of 3166 of anurans belonging to 21 species, of 12 genera and eight families was recorded within these transects (Table 1). No caecilian was observed in Meghamalai during this study. The transect Mavadi had the highest record of 19 species and the least in Suruli (15 species). Thirteen species were observed in

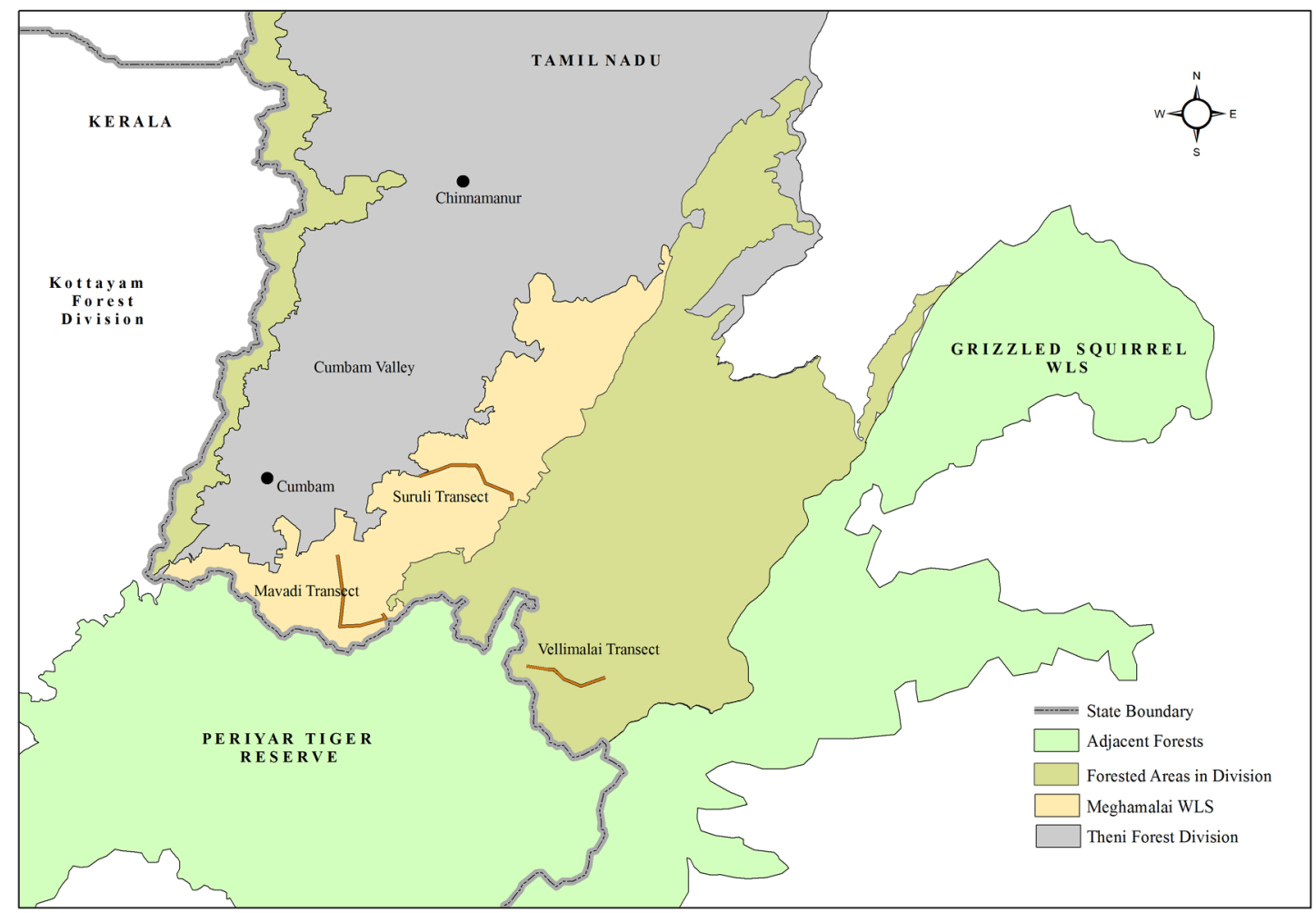

Figure 1. Map of Meghamalai showing belt transects used for sampling anurans. 
all transects, whereas three species were found only in two transects. Five species were recorded only in one transect; three species in Mavadi and two in Vellimalai (Table 1). Indirana beddomii (731 individuals) is the most common species observed followed by Hylarana temporalis (647) in all transects sampled.

Mavadi and Vellimalai transects had a higher number of anuran species and exclusive species (herein referred as restricted to one transect). Higher anuran species richness in the above transects could be due to the presence of wet forests (tropical evergreen forest) and many streams. Suruli area is relatively dry and has a few seasonal streams (Srinivas unpublished data). Vasudevan et al. (2001) reported that amphibian distribution in the Western Ghats is largely restricted to forests adjoining streams.

In the present study, 19 species were recorded in TCVES, 14 in Quadrats, 26 in opportunistic observations (during random walks, night surveys) and six species during monitoring of roads for assessing herpetofaunal mortality due to vehicular traffic. These findings show that adoption of various sampling methods is required to make a reasonable inventory of anurans.

Including a past record (1 species), a total of 35 anuran species are known to occur in the Meghamalai landscape, among them $23(65.7 \%)$ are endemic to the Western Ghats. Boulenger (1891) described Ixalus travancoricus based on a specimen collected from Bodanayakkanur by Ferguson during 1891, deposited at the British Museum Natural History (now Natural History Museum, London). This species is currently known as Raorchestes travancoricus (Dinesh et al. 2012), which has not been recorded during the present study, and no report on its occurrence till the report by Biju \& Bossyut (2009) from Vandiperiyar and Vagaman. However, this species is still categorized under 'Extinct' category in IUCN Red List (2013).

Four recently described species namely, Raorchestes

Table 1. Anuran recorded in various transects surveyed in Meghamalai landscape, Western Ghats between December 2006 and November 2008.

\begin{tabular}{|c|c|c|c|c|c|}
\hline & Species & $\begin{array}{l}\text { Transect } \\
\text { Mavadi }\end{array}$ & $\begin{array}{l}\text { Transect } \\
\text { Suruli }\end{array}$ & $\begin{array}{c}\text { Transect } \\
\text { Vellimalai }\end{array}$ & Total \\
\hline 1 & Duttaphrynus melanostictus & 145 & 90 & 196 & 431 \\
\hline 2 & Duttaphrynus microtympanum & 0 & 0 & 15 & 15 \\
\hline 3 & Euphlyctis cyanophlyctis & 3 & 19 & 41 & 63 \\
\hline 5 & Fejervarya brevipalmata & 31 & 15 & 65 & 111 \\
\hline 4 & Fejervarya mudduraja & 97 & 53 & 15 & 165 \\
\hline 6 & Sphaerotheca breviceps & 2 & 80 & 0 & 82 \\
\hline 7 & Ramanella montana & 1 & 10 & 3 & 14 \\
\hline 8 & Micrixalus fuscus & 28 & 10 & 24 & 62 \\
\hline 9 & Nyctibatrachus beddomii & 13 & 0 & 0 & 13 \\
\hline 10 & Nyctibatrachus major & 30 & 16 & 3 & 49 \\
\hline 11 & Indirana beddomii & 224 & 293 & 214 & 731 \\
\hline 12 & Indirana leptodactyla & 4 & 139 & 19 & 162 \\
\hline 13 & Indirana semipalmata & 15 & 305 & 2 & 322 \\
\hline 14 & Indirana sp.1 & 11 & 0 & 4 & 15 \\
\hline 15 & Hylarana temporalis & 147 & 54 & 446 & 647 \\
\hline 16 & Raorchestes beddomii & 24 & 27 & 68 & 119 \\
\hline 17 & Raorchestes griet & 27 & 40 & 63 & 130 \\
\hline 18 & Raorchestes ponmudi & 0 & 0 & 1 & 1 \\
\hline 19 & Raorchestes sp.1 & 1 & 0 & 0 & 1 \\
\hline 20 & Pseudophilautus wynaadensis & 28 & 4 & 0 & 32 \\
\hline 21 & Ghatixalus variabilis & 1 & 0 & 0 & 1 \\
\hline & Number of species & 19 & 15 & 16 & 21 \\
\hline & Exclusive species & 3 & 0 & 2 & 5 \\
\hline & Number of individuals & 832 & 1155 & 1179 & 3166 \\
\hline
\end{tabular}


griet, R. ponmudi, Rhacophorus pseudomalabaricus and Fejervarya mudduraja were recorded the landscape (Srinivas 2011). Raorchestes ponmudi was described from Ponmudi Hills, Kerala by Biju \& Bossuyt (2005). Raorchestes griet was described by Bossuyt (2002) from Munnar, Kerala. Subsequently, Biju \& Bossyut (2009) reported both Raorchestes ponmudi and Raorchestes griet from Valparai, Anamalai Hills, Tamil Nadu. Rhacophorus pseudomalabaricus was described by Vasudevan \& Dutta (2000) from Anamalai Hills, Tamil Nadu. This species was recorded in Sakkulathumedu, Kerala, which is about $60 \mathrm{~km}$ from Valparai (Srinivas et al. 2009). Kuramoto et al. (2007) described Fajervarya mudduraja based on specimens collected from Coorg, Karnataka. Srinivas (2011) reported this species as common in the landscape.

Meghamalai landscape with 35 species of anurans is comparable with the richness of other localities of the Western Ghats such as Nilgiri Biosphere Reserve (29 species; Easa 1998), Kalakad Wildlife Sanctuary (32 species; Cherian et al. 2000), and KalakadMundanthurai Tiger Reserve (29 species; Vasudevan et al. 2001) and Anamalai Hills (40 species; Kumar et al. 2001). Naniwadekar \& Vasudevan (2007) reported that intensive surveys in any hill range of the Western Ghats documented only 30-50 amphibian species. The species richness of Meghamalai landscape is on par with the other sites in the Western Ghats, thus the landscape is equally important for the anurans and its conservation. High richness of various biota including anurans in Meghamalai area is due to availability of various forest types and wider elevation gradient (Bhupathy et al. 2012).

In Meghamalai, the highest number (18 species) of anurans was recorded from dry deciduous forests, followed by evergreen (15), and shola and grassland and moist deciduous forests (each 13 species). the lowest of six species were recorded in riverine forests. Dry deciduous forests in the landscape are contiguous with human habitations and agricultural fields. Greater habitat diversity has resulted in high species richness. Species inhabiting plains such as Duttaphrynus melanostictus, D. scaber, Euphlyctis cyanophlyctis, E. hexadactylus, Microhyla ornata, M. rubra, Sphaerotheca breviceps, Kaloula taprobanica, Uperodon systoma and Polypedates maculates were found in the area (Srinivas 2011 pers.obser.). Though, the species richness was high in dry deciduous forests, a higher number of endemics was observed in wet forests such as evergreen forests and montane shola-grasslands.

Of the 35 species recorded from the landscape, threat status assessment is available for only 31 species (Table 2). Fajervarya mudduraja is a recently described species, and one species of the genus Raorchestes and Indirana could not be identified up to species level. Threat status of anurans recorded from Meghamalai landscape is given in Table 2. $R$. travancoricus is listed as 'Extinct', despite the report of this species by Biju \& Bossyut (2009) in recent years. Several anurans of the area are listed under 'Critically Endangered' (Rhacophorus pseudomalabaricus, Raorchestes griet, R. ponmudi) and 'Endangered' (Nyctibatrachus aliciae, N. beddomii, Indirana leptodactyla, Pseudophilautus wynaadensis, Ghatixalus variabilis). The actual threat status of recently described species (see above), and Fejervarya brevipalmata evaluated as 'Data Deficient' will be known only after further studies.

\section{REFERENCES}

Bhupathy, S. \& N. Sathishkumar (2013). Status of reptiles in Meghamalai and its environs, Western Ghats, Tamil Nadu, India. Journal of Threatened Taxa 5(15): 4953-4961; http://dx.doi. org/10.11609/JoTT.o3595.4953-61

Bhupathy, S., G. Srinivas \& N. Sathishkumar (2009). A study on herpetofaunal communities of the Upper Vaigai Plateau, Western Ghats, India. Final Technical Report submitted to Ministry of Environment and Forests, Government of India.

Bhupathy, S., G. Srinivas, N. Sathishkumar, T. Karthik \& A. Mathivanan (2011). Herpetofaunal mortality due to vehicular traffic in the Western Ghats, India: A case study. Herpetotropicos 5(2): 119126.

Bhupathy, S., G. Srinivas, N. Sathishkumar, M. Murugesan, S. Babu, R. Suganthasakthivel \& P. Sivakumar (2012). Diversity and conservation of selected biota of the Meghamalai landscape, Western Ghats, India. Current Science 102(4): 590-595.

Biju, S.D. \& F. Bossuyt (2005). A new species of frog (Ranidae, Rhacophorinae, Philautus) from the rainforest canopy in the Western Ghats, India. Current Science 88(1): 175-178.

Biju, S.D. \& F. Bossuyt (2009). Systematics and phylogeny of Philautus Gistel, 1848 (Anura, Rhacophoridae) in the Western Ghats of India, with descriptions of 12 new species. Zoological Journal of the Linnean Society 155(2): 374-444; http://dx.doi.org/10.1111/j.10963642.2008.00466.x

Bossuyt, F. (2002). A new species of Philautus (Anura: Ranidae) from the Western Ghats of India. Journal of Herpetology 36(4): 656-661; http://dx.doi.org/10.1670/0022-1511(2002)036[0656:ANSOPA]2.0 .CO;2

Boulenger, G.A. (1891). Description of a new species of frog obtained by Mr. H.S. Ferguson in Travancore. Southern India. Journal of the Bombay Natural History Society 6(4): 450.

Cherian, P.T., K.R. Devi \& M.S. Ravichandran (2000). Ichthyo and herpetofaunal diversity of Kalakad WildlifeSanctuary. Zoos' Print Journal 15(2): 203-206; http://dx.doi.org/10.11609/JoTT. ZPJ.15.2.203-6

Daniels, R.J.R. (2005). Amphibians of peninsular India. Indian Academy of Sciences, Universities Press, Hyderabad.

Dinesh K.P. \& C. Radhakrishnan (2011). Checklist of amphibians of Western Ghats. Frog leg 16: 15-21.

Dinesh, K.P., C. Radhakrishnan, K.V. Gururaja, K. Deuti \& G. Bhatta (2012). A Checklist of Amphibia of India with IUCN Red list Status. Updated till September 2012. <http://zsi.gov.in/checklist/ 
Table 2. Anuran fauna of Meghamalai landscape, Western Ghats and their threat status as per IUCN Red List 2013.

\begin{tabular}{|c|c|c|}
\hline & Family / Species & IUCN status \\
\hline & Bufonidae & \\
\hline 1 & Duttaphrynus melanostictus (Image 1) & LC \\
\hline 2 & Duttaphrynus microtympanum* & VU \\
\hline \multirow[t]{2}{*}{3} & Duttaphrynus scaber & LC \\
\hline & Dicroglossidae & \\
\hline 4 & Euphlyctis cyanophlyctis & LC \\
\hline 5 & Euphlyctis hexadactylus & LC \\
\hline 6 & Fejervarya brevipalmata* & DD \\
\hline 7 & Fejervarya mudduraja* & NA \\
\hline 8 & Hoplobatrachus tigerinus & LC \\
\hline \multirow[t]{2}{*}{9} & Sphaerotheca breviceps & LC \\
\hline & Microhylidae & \\
\hline 10 & Kaloula taprobanica (Image 2) & LC \\
\hline 11 & Microhyla ornata & LC \\
\hline 12 & Microhyla rubra & LC \\
\hline 13 & Ramanella montana* & NT \\
\hline \multirow[t]{2}{*}{14} & Uperodon systoma & LC \\
\hline & Micrixalidae & \\
\hline \multirow[t]{2}{*}{15} & Micrixalus fuscus* & NT \\
\hline & Nyctibatrachidae & \\
\hline 16 & Nyctibatrachus aliciae* & EN \\
\hline \multirow[t]{2}{*}{17} & Nyctibatrachus beddomii* & EN \\
\hline & Ranixalidae & \\
\hline 18 & Indirana beddomii* & LC \\
\hline 19 & Indirana leptodactyla* & EN \\
\hline 20 & Indirana semipalmata* & LC \\
\hline \multirow[t]{2}{*}{21} & Indirana sp1* & NA \\
\hline & Ranidae & \\
\hline 22 & Clinotarsus curtipes* & NT \\
\hline \multirow[t]{2}{*}{23} & Hylarana temporalis (Image 3) & NT \\
\hline & Rhacophoridae & \\
\hline 24 & Raorchestes beddomii* & NT \\
\hline 25 & Raorchestes griet* & $C R$ \\
\hline 26 & Raorchestes ponmudi* & $\mathrm{CR}$ \\
\hline 27 & Raorchestes travancoricus* & EX \\
\hline 28 & Raorchestes sp1* & NA \\
\hline 29 & Raorchestes sp2* & NA \\
\hline 30 & Pseudophilautus wynaadensis* & EN \\
\hline 31 & Ghatixalus variabilis* & EN \\
\hline 32 & Polypedates maculatus & LC \\
\hline 33 & Polypedates pseudocruciger* & LC \\
\hline 34 & Rhacophorus malabaricus* (Image 4) & LC \\
\hline 35 & Rhacophorus pseudomalabaricus* (Image 5) & CR \\
\hline
\end{tabular}

* Species endemic to Western Ghats; IUCN Threat Category as in Red List 2013: EX - Extinct from wild; CR - Critically Endangered; EN - Endangered;

VU - Vulnerable; NT - Near Threatened; DD - Data Deficient; LC - Least Concern; NA - Not Assessed.

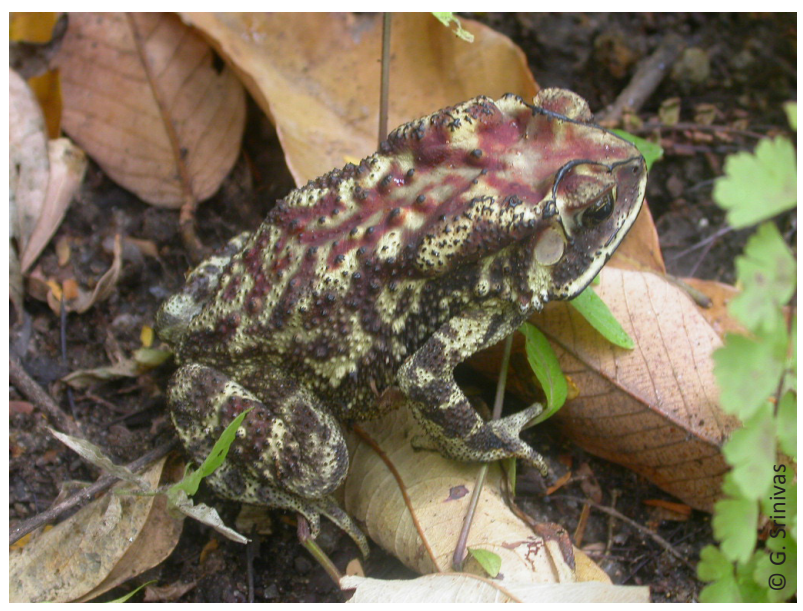

Image 1. Duttaphrynus melanostictus

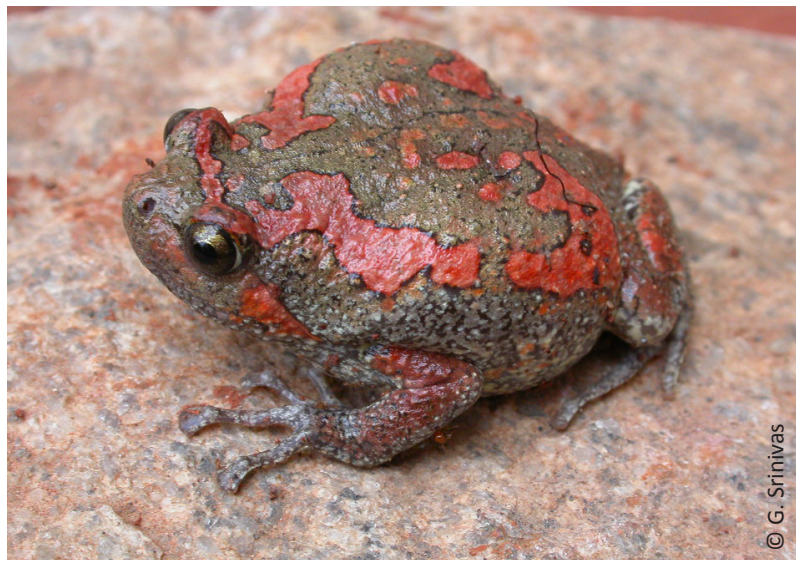

Image 2. Kaloula taprobanica

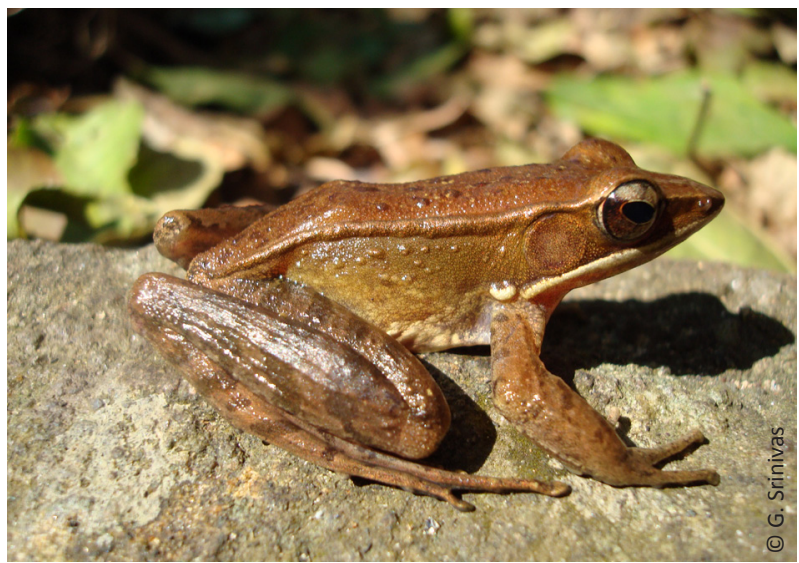

Image 3. Hylarana temporalis 


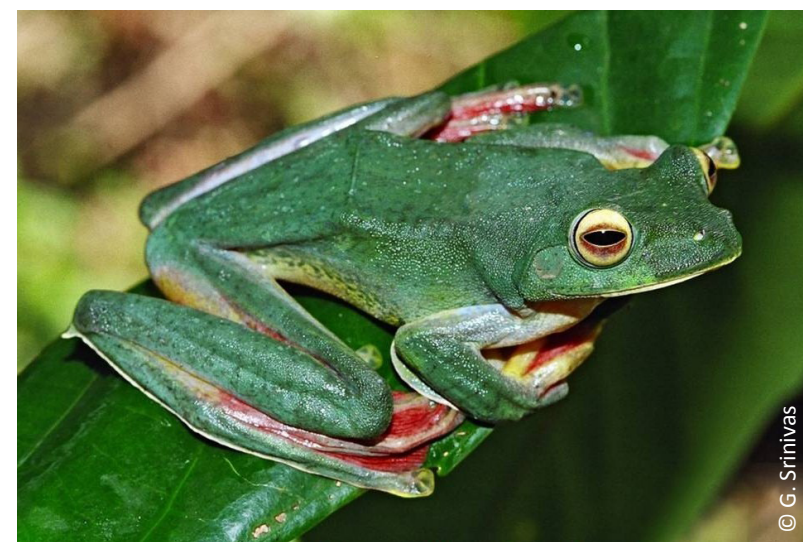

Image 4. Rhacophorus malabaricus

Amphibia_final.pdf $>$ downloaded on 25 December 2012.

Easa, P.S. (1998). A report on the herpetofauna of the Periyar Tiger Reserve. KFRI Research Report No. 148, 40pp

Frost, D.R. (2013). Amphibian Species of the World: an Online Reference. Version 5.6 (9January2013).ElectronicDatabase accessible at <http://research.amnh.org/ herpetology/amphibia/ index.html> American Museum of Natural History, New York, USA Downloaded on 1 March 2013.

Heyer, W.R., M.A. Donnelly, R.W. McDiarmid, L.C. Hayek \& M.S. Foster (1994). Measuring and Monitoring Biological Diversity: Standard Methods for Amphibians. Smithsonian Institution Press, Washington.

IUCN (2013). IUCN Red List of Threatened Species. Version 2013.1 $<$ www.iucnredlist.org>. Downloaded on 02 August 2013.

Kuramoto, M., S.H. Joshy, A. Kurabayashi \& M. Sumida (2007). The Genus Fejervarya (Anura: Ranidae) in central Western Ghats, India, with descriptions of four new Cryptic Species. Current Herpetology 26(2): 81-105; http://dx.doi.org/10.3105/18811019(2007)26[81:TGFARI]2.0.CO;2

Kumar, A., R.Chellam, B.C. Choudhury, D.Muddappa, K. Vasudevan N.M. Ishwar \& B.Noon (2001). Impact of rainforest fragmentation

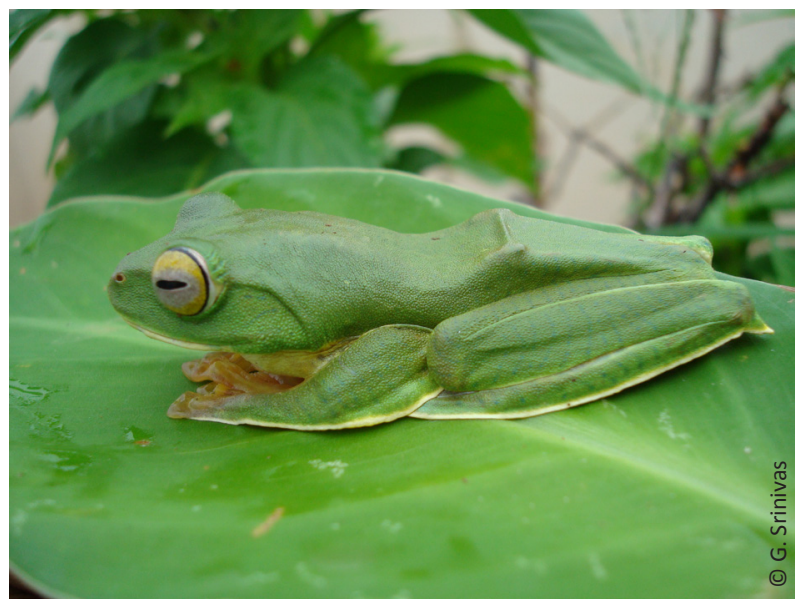

Image 5. Rhacophorus pseudomalabaricus

on small mammals and herpetofauna in the Western Ghats, south India. A summary of research findings. Wildlife Institute of India, Dehra Dun.

Naniwadekar, R. \& K. Vasudevan (2007). Patterns in diversity of anurans along an elevational gradient in the Western Ghats, south India. Journal of Biogeography 34(5): 842-853; http://dx.doi. org/10.1111/j.1365-2699.2006.01648.x

Srinivas, G., S. Bhupathy \& S.R. Suganthan (2009). Rhacophorus pseudomalabaricus (False Malabar Tree Frog). Herpetological Review 40(3): 362.

Srinivas, G. (2011). Distribution Pattern of Amphibians in Megamalai Landscape, Western Ghats, Tamil Nadu. PhD Thesis. Submitted to the Bharathiar University, Coimbatore, 144pp.

Vasudevan, K. \& S.K. Dutta (2000). A new species of Rhacophorus (Anura: Rhacophoridae) from the Western Ghats, India. Hamadryad 25(1): 21-28.

Vasudevan, K., A. Kumar \& R. Chellam (2001). Structure and composition of rain forest floor amphibian communities in KalakadMundanthurai Tiger Reserve. Current Science 80: 405-412. 